\title{
PReS-FINAL-2219: Evaluation of autonomic function in FMF
}

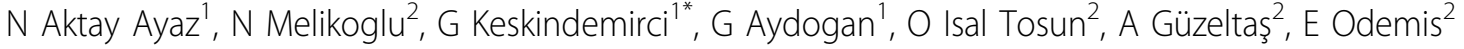 \\ From 20th Pediatric Rheumatology European Society (PReS) Congress \\ Ljubljana, Slovenia. 25-29 September 2013
}

\begin{abstract}
Introduction
Familial Mediterranean fever (FMF) is characterized by acute and recurrent attacks of fever and polyserositis. It is associated with conduction disturbances and rhythm abnormalities. Heart rate variability (HRV) is the term used to indicate the fluctuation in cardiac frequency over time. HRV analysis is used to evaluate the condition of the autonomous nervous system, which regulates general cardiac condition and cardiac activity. Significant correlations between cardiovascular mortality and the autonomous nervous system have been evidenced in the last twenty years. In adult FMF patients abnormal heart rate variability (HRV) parameters were found, suggesting to autonomic dysfunction.
\end{abstract}

\section{Objectives}

To assess cardiac autonomic functions in FMF patients during childhood period.

\section{Methods}

A prospective randomized clinical trial was performed by a tertiary referral pediatric cardiology and a pediatric rheumatology center. The study group consisted of 53 patients with FMF (28 female, 25 male) that were followed-up by the pediatric rheumatology outpatient clinic. They were all under colchicine treatment. The control group was chosen from age and sex matched 44 healthy children ( 21 female, 23 male). All participants underwent 24-hour Holter rhythm monitoring (CardioNavigator Plus Impresario Medical Spider view, 3.07.0158, Delmar Reynolds; Paris, France). The HRV parameters were evaluated in both groups.

${ }^{1}$ Kanuni Sultan Suleyman Education and Research Hospital, Istanbul, Turkey Full list of author information is available at the end of the article

\section{Results}

The mean age of the study group was $11.6 \pm 3.5$ years and the control group was $10.4 \pm 3.4$ years. Height and weight of the study group were $143.2 \pm 19 \mathrm{~cm}$ and $37.9 \pm 11.7 \mathrm{~kg}$ respectively. The control group's height and weight were $143.6 \pm 18.1 \mathrm{~cm}$ and $38.5 \pm 14.1 \mathrm{~kg}$ respectively. The mean duration of colchicine treatment was $43.4 \pm 41.5$ months. The time-domain analysis of HRV revealed similar values of mean "standard deviation of all $\mathrm{NN}$ intervals" (SDNN;152.3 \pm 46.2 vs $143.13 \pm 41.99 \mathrm{msec}, \mathrm{p}=0.423$ ), "SD of the 5 min mean RR intervals" (SDANN;131.3 \pm 36.3 vs $128.6 \pm 36.5 \mathrm{msec}, \mathrm{p}=0.451$ ), "root square of successive differences in RR interval" (RMSSD; $70.8 \pm 53.5$ vs $69 \pm 33.6 \mathrm{msec}, \mathrm{p}=0.481$ ), and "proportion of differences in successive NN intervals $>50 \mathrm{~ms}$ " (PNN50; $21.2 \pm 14$ vs $21.3 \pm 12.1 \%, \mathrm{p}=0.524)$, "triangular interpolation of $\mathrm{NN}$ interval histogram" (TINN; $623 \pm 219$ vs $615 \pm 170 \mathrm{msec}$, $\mathrm{p}=0.451)$ and "HRV index" $(20.8 \pm 6.8$ vs $20.3 \pm 5.2$ msec, $\mathrm{p}=0.633$ ) in both groups. Frequency domain analysis revealed similar values of high frequency (HF; $48.2 \pm$ 13.9 vs $46.3 \pm 14.8, \mathrm{p}=0.451$ ), low frequency (LF; $42.5 \pm$ 12.7 vs $44 \pm 15.3, \mathrm{p}=0.451)$ and $\mathrm{LF} / \mathrm{HF}(1.08 \pm 0.84$ vs $1.31 \pm 1.5, \mathrm{p}=0.542$ ) components in both groups.

\section{Conclusion}

Autonomic nervous system has an important role in the supervision of cardiac functions. In adult patients with uncomplicated FMF there are two published studies about the autonomic dysfunction, one revealing autonomic indices abnormalities and the other with similar normal autonomic function compared to healthy subjects. As being the first study concerning the autonomic function in children with FMF, we had found no significant differrences between both groups. This may be atrributed to the shorter duration and uncomplicated course of disease in children with FMF. 


\section{Disclosure of interest}

None declared.

\section{Authors' details}

${ }^{1}$ Kanuni Sultan Suleyman Education and Research Hospital, Istanbul, Turkey.

${ }^{2}$ Mehmet Akif Ersoy E. R. H., Istanbul, Turkey.

Published: 5 December 2013

doi:10.1186/1546-0096-11-S2-P209

Cite this article as: Aktay Ayaz et al:: PReS-FINAL-2219: Evaluation of

autonomic function in FMF. Pediatric Rheumatology 2013

11(Suppl 2):P209.

Submit your next manuscript to BioMed Central and take full advantage of:

- Convenient online submission

- Thorough peer review

- No space constraints or color figure charges

- Immediate publication on acceptance

- Inclusion in PubMed, CAS, Scopus and Google Scholar

- Research which is freely available for redistribution

Submit your manuscript at www.biomedcentral.com/submit
Ciomed Central 